\title{
QUALITY OF WELL WATER INTENDED FOR WATERING PIGS: ANALYSES OF BACTERIOLOGICAL PARAMETERS AND PESTICIDE CONTENT
}

\author{
Dubravka Milanov ${ }^{1 \star}$, Brankica Kartalović1, Nevenka Aleksić2, \\ Gospava Lazić ${ }^{1}$, Nenad Popov ${ }^{1}$, Sava Lazić ${ }^{1}$ \\ ${ }^{1}$ Scientific Veterinary Institute "Novi Sad", Novi Sad, Republic of Serbia \\ ${ }^{3}$ University of Belgrade, Faculty of Veterinary Medicine, Belgrade, Republic of Serbia
}

\section{Abstract}

Water used for watering pigs, originating from five wells located in households in a settlement in Vojvodina, was inspected for its quality by the analysis of bacteriological parameters and pesticide content. Five samples were taken from each well at monthly intervals $(n=25)$. In all water samples from three wells, coliform bacteria, including thermotolerant coliforms and Escherichia coli, indicators of faecal contamination, were repeatedly detected. In the water of all of the five wells organophosphate pesticides were detected, whose maximum allowed concentrations are not defined by the current Serbian Regulations on the quality of drinking water. Given the quantity of water consumed by pigs on a daily basis, water contaminated with coliform bacteria and organophosphate pesticides poses a risk to their health. Diminishing resources of drinking water and the growing environmental pollution, renders the assessment of the quality of water intended for domestic animals necessary as part of the integrated system of management in agricultural holdings.

Keywords: well water, pigs, bacteria, pesticides

\footnotetext{
${ }^{1 \star}$ Corresponding author: dubravka@niv.ns.ac.rs
} 


\title{
ISPITIVANJE HIGIJENSKE ISPRAVNOSTI BUNARSKE VODE ZA NAPAJANJE SVINJA ANALIZOM BAKTERIOLOŠKIH PARAMETARA I SADRŽAJA PESTICIDA
}

\author{
Dubravka Milanov ${ }^{1^{*}}$, Brankica Kartalović1 ${ }^{1}$ Nevenka Aleksić \\ Gospava Lazić1, Nenad Popov ${ }^{1}$, Sava Lazić ${ }^{1}$
}

${ }^{1}$ Naučni institut za veterinarstvo „Novi Sad“, Novi Sad, Republika Srbija ${ }^{2}$ Univerzitet u Beogradu, Fakultet veterinarske medicine, Beograd, Republika Srbija

\section{Kratak sadržaj}

Voda koja se koristi za napajanje svinja, uzorkovana iz pet bunara u domaćinstvima jednog naselja u Vojvodini, ispitana je na higijensku ispravnost analizom bakterioloških pokazatelja i sadržaja pesticida. Iz svakog bunara ukupno je uzeto po pet uzoraka $(\mathrm{n}=25)$, u mesečnim intervalima. $\mathrm{U}$ svim uzorcima vode iz tri bunara ustanovljene su koliformne bakterije, uključujući i indikatore fekalne kontaminacije - termotolerantne koliforme i Escherichia coli. U vodi svih pet bunara ustanovljeni su pesticidi iz grupe organofosfatnih jedinjenja, za koje u aktuelnom Pravilniku o higijenskoj ispravnosti vode za piće Republike Srbije, ne postoje definisane maksimalne dozvoljene koncentracije. S obzirom na količinu vode koju svinje unose na dnevnom niovu, voda kontaminirana koliformnim bakterijama i organofosfatnim pesticidima predstavlja rizik za njihovo zdravlje. Smanjenje resursa pijaće vode i sve intenzivnije zagađenje životne sredine nameću potrebu da ispitivanje kvaliteta vode za napajanje domaćih životinja bude deo integrisanog sistema upravljanja poljoprivrednim gazdinstvima.

Ključne reči: bunarska voda, svinje, bakterije, pesticidi

\section{INTRODUCTION}

Besides balanced diet, the most important prerequisite for animal health protection and welfare, and optimum production is the provision of ample fresh drinking water (Smith, 2020). Generally, a domestic animal can survive feed deprivation for two months, but without water merely a week. Insufficient watering leads to stress, poor performance and, eventually, to dehydration (Landefeld and Bettinger, 2003). Depending on animal species, category and age, water make up $44-88 \%$ of their body mass and is necessary for ingestion and feed digestion, 
dissolving and transport of inorganic and organic matter (both within the body and in order of excretion), biochemical processes, maintaining homeostasis, metabolite excretion, thermoregulation, reproduction and other vital functions of the organism (Manu and Baidoo, 2020). Fattening pigs (body weight $20-110 \mathrm{~kg}$ ) need 3-12 L of water on a daily basis, depending on body weight (weaners 3-5 L, growers 5-7 L and finishers 9/12 L), boars and dry sows 12-15 L, and lactating sows even up to almost $50 \mathrm{~L}$ (24-45 L) (Dawson, 2020). Daily water intake may be considered a sensitive indicator of animal health and welfare, and is also closely related to feed consumption (AHDB, 2019; Bigelow and Houpt, 1988). The quality of water, influencing feed intake, feed conversion and growth rate, is of high importance for animals. Water intended for consumption must be of corresponding physical and chemical quality, and without harmful and toxic substances. The quality of water used for watering animals should correspond to the one which is used by humans (Radivojević, 2004), which is in the Republic of Serbia defined in the Regulations on the quality of drinking water (Official Gazette of the FRY Nos. 42/98 and 44/99, and Official Gazette of the RS No. 28/2019).

Water quality is influenced by a range of factors: sand or sludge particles, increased concentrations of chemical elements, contamination with microbes, pesticides, radionuclides etc. The most frequent microbial contaminants of drinking water are bacteria originating from soil and plants, septic tanks and sewers or flood waters, which regularly contain large numbers of microorganisms due surface layers of soil being washed away, or insects and rodents which may enter wells. Surface and underground waters are often contaminated with pesticides due to their wide use in plant protection, which are commonly used in higher concentrations/ quantities and more frequently than recommended by their instructions on use. There is a scarcity of data on the microbiological quality of water and pesticide concentrations in water intended for animal watering. Given that water intake in pigs corresponds to $10 \%$ of their body mass, and is twice as much as ingested feed, it is surprising that so little attention has been devoted to research into the quality of water in comparison to that of feed. This prompted us to set the aim of this work - assessment of hygienic correctness of well water which is used for watering pigs by assessing bacteriological parameters and pesticide content.

\section{MATERIAL AND METHODS}

\section{Water samples}

Water from five dug wells located in the same settlement in the Autonomous Province of Vojvodina (Serbia) was subjected to research. The wells were located in separate households which grow and fatten pigs and the meat 
product use for their own needs and sell them on the local market. The wells were dug, (natural waters, open spring), and the water was obtained by turning on the taps. The water is used for watering pigs, maintaining the hygiene in pig houses and as technical water in households. The water was sampled five times, in monthly intervals, from October 2019 to March 2020. Before each sampling, the plastic opening of the tap was disinfected with $70 \%$ ethanol and the water allowed to flow for 3-5 minutes at a steady rate. The water was sampled in sterile $500 \mathrm{~mL}$ glass bottles filled up to $1-2 \mathrm{~cm}$ below the top. The bottles were closed and transported to the laboratory at temperature $<5^{\circ} \mathrm{C}$. Bacteriological assessment began on the arrival of water samples and the remaining samples kept for pesticide tests in a refrigerator.

\section{Bacteriological assessment}

In water samples the presence of the following bacteria were determined: the total number of coliform bacteria, Escherichia coli, faecal coliforms, intestinal enterococci, Pseudomonas aeruginosa and Clostridium perfringens. All analyses were done using the membrane filtration method, with sterile membrane filters with a sieve, diameter $47 \mathrm{~mm}$ and pore diameter $0.45 \mu \mathrm{m}$ (FilterLab Gridded MCE Membrane Filter, Filtros Anoia, S.A., Barcelona, Spain). For each analysis $100 \mathrm{~mL}$ of water was filtered. Bacterium isolation and identification was done with the following methods:

- Enumeration of Escherichia coli and coliform bacteria (ISO 9308-1:2014). The filters were placed on the surface of Chromogenic Coliform Agar (ISO, CM 1205, Oxoid Ltd., Basingstoke, UK), and the plates incubated for $24 \mathrm{~h}$ at $37^{\circ} \mathrm{C}$. To determine the total numbers of thermotolerant (faecal) coliforms, the plates were incubated for $24 \mathrm{~h}$ at $44^{\circ} \mathrm{C}$. For species confirmation, the oxidase test (negative) and the indole test (positive in E. coli) were used.

- Detection and enumeration of intestinal enterococci (ISO 7899-2:2000). The filters were placed on the surface of Slanetz and Bartley Medium (CM0377, Oxoid Ltd., Basingstoke, UK). The plates were incubated for $48 \mathrm{~h}$ at $37^{\circ} \mathrm{C}$. For confirmation Bile Aesculin Azide Agar (Oxoid Ltd., Basingstoke, UK) was prepared.

- Detection and enumeration of Pseudomonas aeruginosa (ISO 162662:2018). The membrane filters were placed on the surface of Pseudomonas Cetrimide agar (CM0579, Oxoid Ltd, Basingstoke, UK), and the plates incubated at $37^{\circ} \mathrm{C}$ for $44 \mathrm{~h}$. For confirmation the oxidase test and the failure of growth at $4^{\circ} \mathrm{C}$ after 5-day incubation were used.

- Enumeration of Clostridium perfringens (ISO 14189:2013). The filters were placed on the Tryptose Sulphite Cycloserine Agar (TSC Agar) (Perfrin- 
gens agar base CM 0587 with D-cycloserine SR0088, Oxoid Ltd., Basingstoke, $\mathrm{UK})$. The plates were incubated for $24 \mathrm{~h}$ at $44^{\circ} \mathrm{C}$ in anaerobic conditions using GasPak EZ (Becton Dickinson and Co., Franklin Lakes, NJ, USA).

After the incubation ceased, the plates were inspected, confirmation tests for identification performed and the colonies characteristic of the targeted species counted. The results were expressed as the absence of bacteria, real number in $100 \mathrm{~mL}(\mathrm{CFU} / 100 \mathrm{~mL})$ of water, or too numerous to determine their exact number (too numerous to count - TNTC).

\section{Pesticide content}

Water was tested for the presence of organochlorine pesticides (aldrin, dieldrin, endrin, endosulfan I, endosulfan II, endosulfan sulphate, p,p'-DDD, p,p'-DDT, p,p'-DDE, heptachlor, heptachlor epoxide, cis-chlordane, transchlordane, alfa $\mathrm{BHC}$, beta $\mathrm{BHC}$, lindane, delta $\mathrm{BHC}$, methoxychlor, endrin aldehyde) and organophosphate pesticides (thionazin, sulfotep, phorate, dimethoate, disulfoton, methyl parathion, parathion). The samples were prepared by liquid-liquid extraction: mixing with an organic solvent (methylene chloride), separation of the organic phase, concentration of the extracts by vaporisation in nitrogen flow and reconstitution of the dry residue with nhexane (EPA 1699/2007). For the preparation of calibration solution, mixtures of standard solutions of organochlorine pesticides were used (PPM-808C-1, Agilent) and mixtures of standard solutions of organophosphate pesticides (ERO-008, Supelco Analytical). To eliminate the influence of the matrix on the results, a calibration through matrix was done according to SANTE 12682 (EC 2019) document. As a blank sample, distilled water without pesticides was used. The analyses were done with the method of gas chromatography coupled to mass detector. Pesticide content was determined in Agilent system GC/MS. System GS 7890B was connected to the mass spectrometer of the mass selective detector 5977A. The mass spectrometer worked at the EI mode at $70 \mathrm{eV}$. A capillary column (30 m $\times 0.25 \mu \mathrm{m}$ film HP-5 M-thickness) which contains $5 \%$ diphenyl and 95\% dimethylpolysiloxane (HP-5MS, Agilent Technologies, Inc., Santa Clara, CA, USA) was deployed. Data collection and processing was done using MassHunter Software (Agilent, Santa Clara, CA, USA).

\section{RESULTS AND DISCUSSION}

Bacterial pollution of water has traditionally been expressed as the number of coliform bacteria in a certain water volume. Given that they are normal inhabitants of animal and human guts, their presence in water is an indica- 
tor of faecal pollution (Gonzalez et al., 1992; LeChevallier et al., 1996; Kilb et al., 2003; Paruch and Maehlum, 2012; Ercumen et al., 2017). However, coliform bacteria species of the Klebsiella, Citrobacter and Enterobacter genus are also ubiquitous in nature, soil, vegetation and in surface waters (Barcina et al., 1990), which mean that their presence is not necessarily related to faecal contamination (Leclerc et al., 2001). For this reason, later has been made a distinction of so-called "thermotolerant" coliforms as specific indicators of faecal contamination (Leclerc et al., 2001; WHO, 1997), from the total coliforms. Faecal coliform determinations should be complemented with the quantification of enterococci (Cabral, 2010). Non-coliform species such as Pseudomonas aeruginosa (Fig 2.) and bacteria species of the Clostridium genus (Leclerc et al., 2001) have been used as additional indicators of the microbial safety of drinking water. In spite of being less specific indicators of faecal contamination than E. coli, Enterococci are more advantageous indicators of contamination: they are more resistant to disinfectants used for drinking waters, they survive better and may be transported further than E. coli and thermotolerant coliforms. For these reasons, enterococci may be detected even when E. coli cannot (Health Canada, 2020).

The recommendations by the Australian and New Zealand Environment and Conservation Council set the limit to $<100$ thermotolerant (faecal) coliforms per $100 \mathrm{~mL}$ of livestock drinking water (Davis, 2016). By contrast, the US EPA's recommendation for livestock water is $<5,000$ coliforms per $100 \mathrm{~mL}$, but faecal coliforms $<1$ (Pfost and Fulhage, 2020).

The analysis of water samples $(n=25)$ from five wells detected coliform bacteria in 15 samples originating from three wells, but their precise numbers in five samples could not have been determined (Table 1; Figure 1). Thermotolerant coliforms, a sub-group of total coliforms, were isolated from six water samples, and in five a thermotolerant Escherichia coli was detected, whilst Clostridium perfringens and faecal enterococci, additional indicators of faecal contamination, were not confirmed. Due to the presence of coliform bacteria, especially of thermotolerant coliforms (including E. coli), the use of water from these wells for watering pigs could be estimated as a biological risk for their health. It could be of especial importance in warm periods of the year owing to the indirect/direct influence of temperature on a series of chemical and physical parameters of water and because temperature is the most important factor affecting bacterial growth (LeChevallier et al., 1996). The current research was done in autumn and winter (October 2019-March 2020), but E. coli and other enteric bacteria, being mesophilic, grow faster alongside the rise in water temperature above $15^{\circ} \mathrm{C}$ (LeChevallier et al., 1996). Thus, higher incidence of 
animal water-borne infection with $E$. coli has been supposedly related to the increase in the bacterium numbers in water in summer (Hancock et al., 1994).

According to the Regulations on the quality of drinking water (Official Gazette of the FRY, Nos. 42/98 and 44/99, and Official Gazette of the RS No. 28/2019), natural waters in open springs (dug wells) may contain up to 10 $\mathrm{CFU} / 100 \mathrm{~mL}$ of coliform bacteria (determined by the method of membrane filtration). In comparison with this criterion, the water in three wells (Nos. 1,2 and 3) was of inadequate microbial quality. However, it remains unclear whether water intended for watering pigs has to abide the guidelines defined for water for human consumption. In literature diverse standards of acceptable water quality can be found, for instance: 1,000 total coliforms/100 mL and 50 Escherichia coli/100 $\mathrm{mL}$ in water intended for pigs (Edwards, 2018), or that water used for livestock should not contain more than 5,000 coliforms/100 mL (National Research Council, 1998). According to the Alltech factsheet on water quality in pig production, a total of 50 colony forming units (cfu) is acceptable, but numbers beyond $100 \mathrm{cfu} / \mathrm{ml}$ require treatment (Epp, 2019). However, E. coli water contamination was confirmed as a reality by the assessment of 98 dairy farms in the USA, which revealed the average log10-transformed coliform and E. coli concentrations per milliliter of water $1.76 \pm 1.25$ and 0.98 \pm 1.06 , respectively (LeJeune et al., 2001). The contamination level of the water provided to livestock correlated positively with the proximity of the water containers to the feeders, protection of the water from direct sunlight and higher weather temperatures (LeJeune et al., 2001). 
Table 1: Results of bacteriological research on well water for pig watering $(n=25)$

\begin{tabular}{|c|c|c|c|c|c|c|c|c|}
\hline \multirow[b]{2}{*}{$\begin{array}{l}\text { Samp- } \\
\text { ling }\end{array}$} & \multirow[b]{2}{*}{$\begin{array}{c}\text { Sample } \\
\text { No. }\end{array}$} & \multicolumn{7}{|c|}{ Numbers of bacteria (CFU/100 mL) } \\
\hline & & $\begin{array}{l}\text { Coli- } \\
\text { forms }\end{array}$ & $\begin{array}{c}\text { Faecal } \\
\text { coli- } \\
\text { forms }\end{array}$ & E. coli & $\begin{array}{l}\text { Faecal } \\
\text { E. coli }\end{array}$ & $\begin{array}{c}\text { Ps. } \\
\text { aerug. }\end{array}$ & $\begin{array}{c}\text { Faecal } \\
\text { en- } \\
\text { teroc. }\end{array}$ & $\begin{array}{c}\text { Cl. } \\
\text { perfring }\end{array}$ \\
\hline \multirow{5}{*}{1} & 1 & 200 & 13 & 44 & 12 & 9 & 0 & 0 \\
\hline & 2 & 78 & 12 & 9 & 6 & 1 & 0 & 0 \\
\hline & 3 & TNTC & 0 & 9 & 0 & 0 & 0 & 0 \\
\hline & 4 & TNTC & 0 & 24 & 0 & 0 & 0 & 0 \\
\hline & 5 & TNTC & 0 & 96 & 0 & 0 & 0 & 0 \\
\hline \multirow{5}{*}{2} & 1 & 58 & 12 & 46 & 12 & 1 & 0 & 0 \\
\hline & 2 & 80 & 4 & 10 & 5 & 7 & 0 & 0 \\
\hline & 3 & 110 & 0 & 0 & 0 & 0 & 0 & 0 \\
\hline & 4 & 90 & 0 & 0 & 0 & 0 & 0 & 0 \\
\hline & 5 & 130 & 0 & 0 & 0 & 0 & 0 & 0 \\
\hline \multirow{5}{*}{3} & 1 & 53 & 5 & 44 & 3 & 0 & 0 & 0 \\
\hline & 2 & 59 & 6 & 10 & 0 & 0 & 0 & 0 \\
\hline & 3 & 120 & 0 & 0 & 0 & 0 & 0 & 0 \\
\hline & 4 & TNTC & 0 & 0 & 0 & 0 & 0 & 0 \\
\hline & 5 & TNTC & 0 & 0 & 0 & 0 & 0 & 0 \\
\hline \multirow{5}{*}{4} & 1 & 0 & 0 & 0 & 0 & 0 & 0 & 0 \\
\hline & 2 & 0 & 0 & 0 & 0 & 0 & 0 & 0 \\
\hline & 3 & 0 & 0 & 0 & 0 & 0 & 0 & 0 \\
\hline & 4 & 0 & 0 & 0 & 0 & 0 & 0 & 0 \\
\hline & 5 & 0 & 0 & 0 & 0 & 0 & 0 & 0 \\
\hline \multirow{5}{*}{5} & 1 & 0 & 0 & 0 & 0 & 0 & 0 & 0 \\
\hline & 2 & 0 & 0 & 0 & 0 & 0 & 0 & 0 \\
\hline & 3 & 3 & 0 & 0 & 0 & 0 & 0 & 0 \\
\hline & 4 & 0 & 0 & 0 & 0 & 0 & 0 & 0 \\
\hline & 5 & 0 & 0 & 0 & 0 & 0 & 0 & 0 \\
\hline
\end{tabular}

TNTC- too numerous to count 

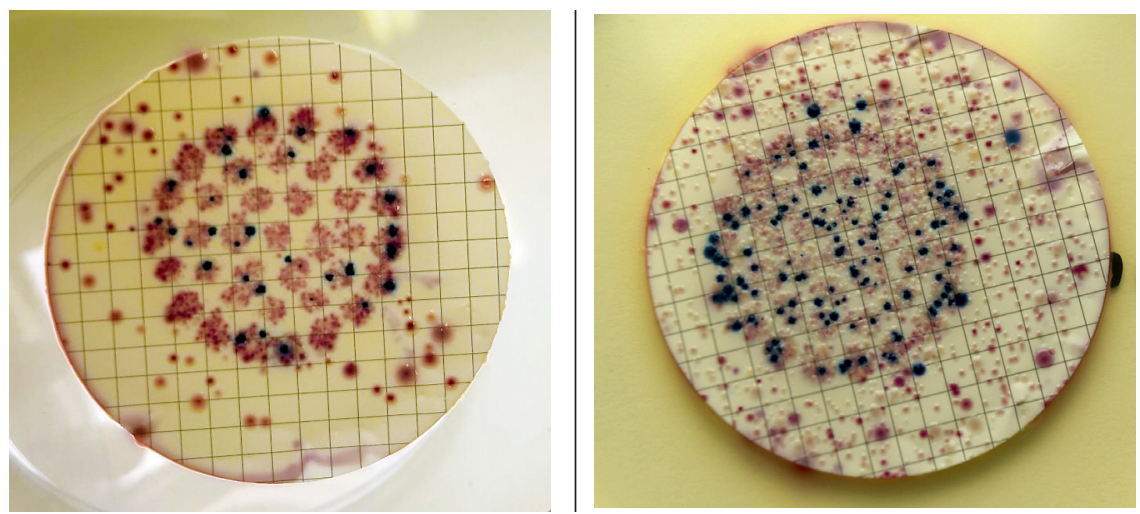

Figure 1. Coliform bacteria (red colonies) and Escherichia coli (violet colonies) on membrane filter incubated for $24 \mathrm{~h}$ at $37^{\circ} \mathrm{C}$ on the surface of Chromogenic Coliform Agar, isolated from water originating from Well No. 1.

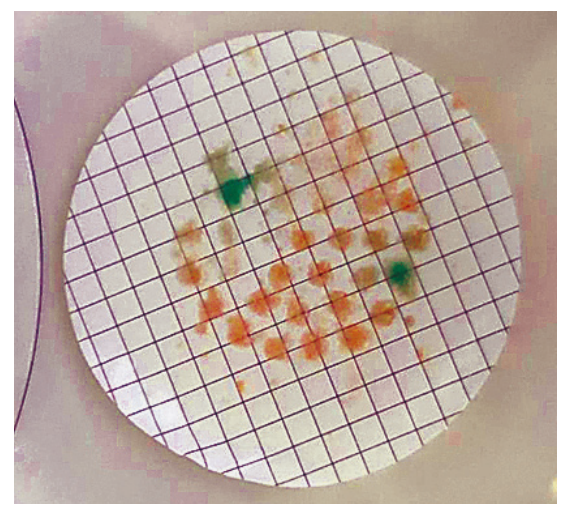

Figure 2. Pseudomonas aeruginosa (green colonies)

The samples of well water were assessed for the presence and content of 26 pesticides, out of which 19 were from the organochlorine class. Although their use was banned in 1970s due to their long half-life, which may be as long as 10-15 years (Jayaraj et al., 2016) they can still be detected in traces (Ramadhaningtyas et al., 2019). The content of all organochlorine pesticides in all water samples tested in this research was below the level of quantitation (LOQ), i.e. below $0.005 \mu \mathrm{g} / \mathrm{L}$ (Figure 3), which is in compliance with the Regulations on the quality of drinking water (Official Gazette of the FRY, Nos. 42/98 and 44/99, and Official Gazette of the RS, No. 28/2019). 


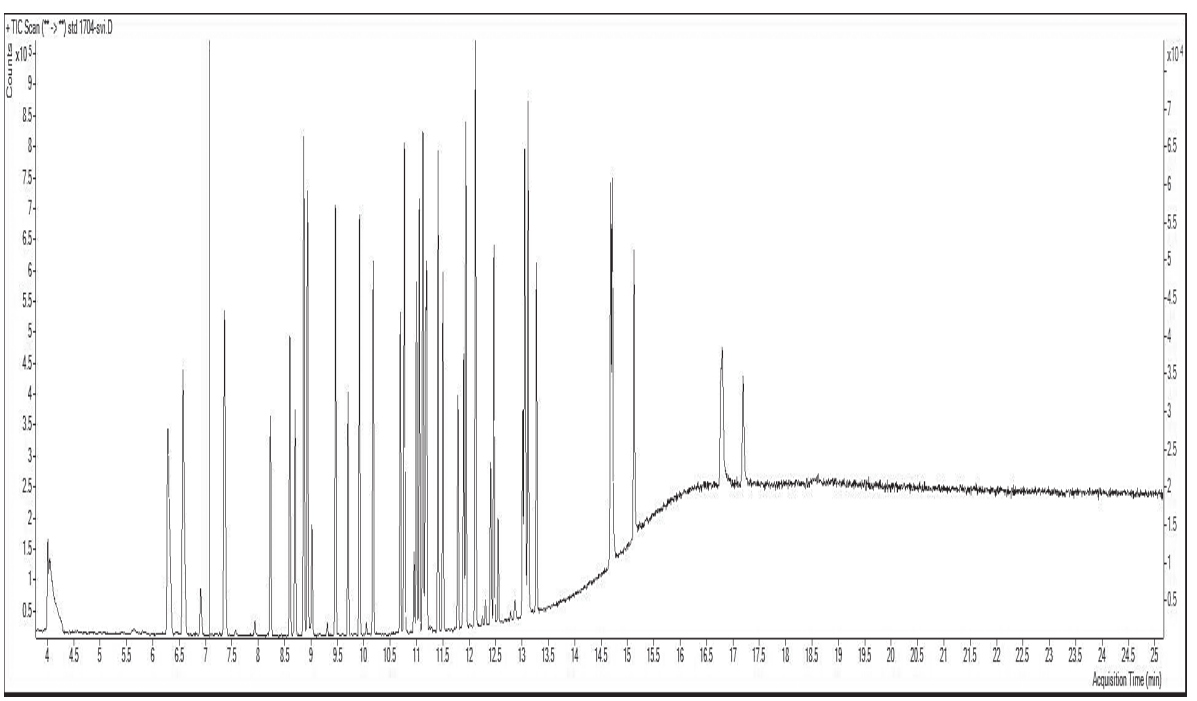

Figure 3. Chromatograph of organochlorine pesticides

However, in water samples from all of the five wells the following organophosphate pesticides were detected: dimethoate, disulfoton and phorate (Table 2, Figure 4), for which the maximum allowable concentrations (MAC) are not defined by legislation (Official Gazette of the FRY, Nos. 42/98 and 44/99, and Official Gazette of the RS, No. 28/2019).

Dimethoate was detected in drinking water supplies in Canada (reservoir water samples in Northern Great Plains) in the concentration of $5.98 \mathrm{ng} / \mathrm{L}$ by Donald et al. (2007), who regrettably underlined that for the majority of herbicides there are no limits established (Donald et al., 2007).

Table 2. Organophosphate pesticides and their concentrations in well water samples

\begin{tabular}{ccccccc}
\hline $\begin{array}{c}\text { Water } \\
\text { from } \\
\text { well No. }\end{array}$ & Pesticide & RT (min) & MW & T & Q1 & Q2 \\
\hline \multirow{2}{*}{1} & Phorate & $<0.005$ & $<0.005$ & $<0.005$ & $\mathbf{0 . 0 0 6}$ & $<0.005$ \\
& Dimethoate & $\mathbf{0 . 0 0 8}$ & $\mathbf{0 . 0 0 9}$ & $\mathbf{0 . 0 0 6}$ & $\mathbf{0 . 0 0 5}$ & $<0.005$ \\
& Disulfoton & $\mathbf{0 . 0 0 6}$ & $\mathbf{0 . 0 0 6}$ & $\mathbf{0 . 0 0 6}$ & $\mathbf{0 . 0 0 5}$ & $<0.005$ \\
& Phorate & $\mathbf{0 . 0 0 7}$ & $\mathbf{0 . 0 0 7}$ & $\mathbf{0 . 0 0 6}$ & $\mathbf{0 . 0 0 6}$ & $<0.005$ \\
2 & Dimethoate & $\mathbf{0 . 0 0 5}$ & $\mathbf{0 . 0 3 6}$ & $\mathbf{0 . 0 0 5}$ & $\mathbf{0 . 0 0 5}$ & $<0.005$ \\
& Disulfoton & $\mathbf{0 . 0 0 7}$ & $\mathbf{0 . 0 0 5}$ & $\mathbf{0 . 0 0 6}$ & $\mathbf{0 . 0 0 5}$ & $<0.005$
\end{tabular}




\begin{tabular}{ccccccc}
\hline $\begin{array}{c}\text { Water } \\
\text { from } \\
\text { well No. }\end{array}$ & Pesticide & RT (min) & MW & T & Q1 & Q2 \\
\hline \multirow{4}{*}{3} & Phorate & $<0.005$ & $<0.005$ & $<0.005$ & $<0.005$ & $<0.005$ \\
& Dimethoate & $\mathbf{0 . 0 0 5}$ & $\mathbf{0 . 0 2 0}$ & $\mathbf{0 . 0 0 5}$ & $\mathbf{0 . 0 0 5}$ & $<0.005$ \\
& Disulfoton & $\mathbf{0 . 0 1}$ & $\mathbf{0 . 0 0 9}$ & $\mathbf{0 . 0 0 7}$ & $\mathbf{0 . 0 0 6}$ & $\mathbf{0 . 0 0 8}$ \\
4 & Phorate & $\mathbf{0 . 0 0 5}$ & $<0.005$ & $<0.005$ & $<0.005$ & $<0.005$ \\
4 & Dimethoate & $\mathbf{0 . 0 0 5}$ & $\mathbf{0 . 0 2 2}$ & $\mathbf{0 . 0 0 5}$ & $<0.005$ & $<0.005$ \\
& Disulfoton & $\mathbf{0 . 0 0 5}$ & $\mathbf{0 . 0 0 5}$ & $<0.005$ & $<0.005$ & $<0.005$ \\
& Phorate & $\mathbf{0 . 0 0 7}$ & $\mathbf{0 . 0 0 6}$ & $<0.005$ & $<0.005$ & $\mathbf{0 . 0 0 6}$ \\
5 & Dimethoate & $\mathbf{0 . 0 0 5}$ & $\mathbf{0 . 0 0 5}$ & $\mathbf{0 . 0 0 5}$ & $<0.005$ & $<0.005$ \\
& Disulfoton & $\mathbf{0 . 0 0 6}$ & $\mathbf{0 . 0 0 5}$ & $<0.005$ & $\mathbf{0 . 0 0 6}$ & $<0.005$ \\
\hline
\end{tabular}

RT-Retention Time; MW- Molecular Weight; T-Target Ion; Q1- Quantifiler Ion 1; Q2- Quantifiler Ion 2.

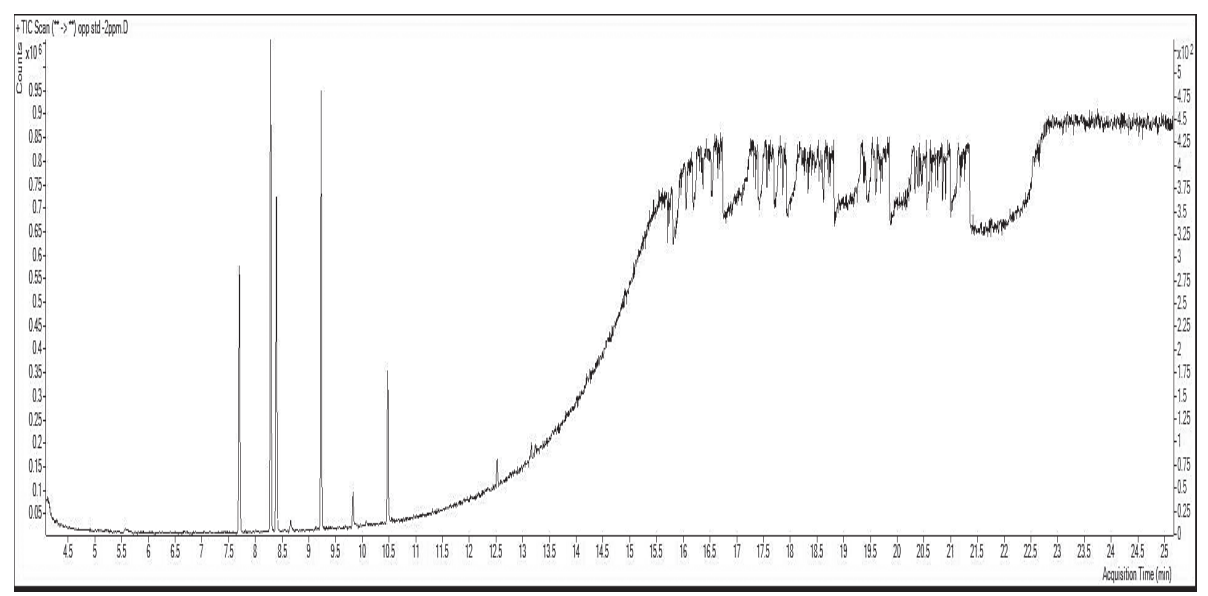

Figure 4. Chromatograph of the organophosphate pesticides

Water pollution with pesticides is a direct consequence of their use in agriculture. Given that they reach underground waters from the surface layers of soil, their quantities are influenced by the river water levels and water flow. Besides by utilizing organophosphorus pesticides, more frequently people may be exposed to them indirectly via water, food or air, which is why the methods of their detection are being continually improved (Liu et al., 2020).

The major mechanism of organophosphorus pesticide toxicity is the inhibition of cholinesterase enzyme (ChE), which has been proven for disulfoton to increase in the process of chlorination (Chu, 2020). ChE inhibition results 
in the accumulation of acetyl choline neurotransmitter and the blocking the nerve impulse transmission. Besides the cessation of neurotransmission, organophosphates and the products of their transformation (oxidation, isomerization and hydrolysis) also exert non-specific toxic action. During acute, and especially during long-lasting exposure to this pesticide group, reactive free oxygen species are produced in the organism, which attack lipids, proteins and DNA, lead to cell membrane damages, enzyme inactivation, genetic damages and, finally, to cell death. It has been known that chronic exposure of rats to small doses of phorate may impair energy-related metabolism and antioxidant system, and may cause liver, kidney and DNA damage (Sun et al., 2014). Increased use of agrochemicals, especially of pesticides, result in the spreading of harmful chemicals in the environment. It is especially important to determine pesticide quantities in underground and surface waters, which are the primary media for the transport of pesticides with low volatility.

Only scarce information is available on the criteria for water given to livestock (Valente-Campos et al., 2014). Little data on the hygienic characteristics of water intended for animal consumption is probably related to the fact that water supply was ample and inexpensive for considerable part of the world (FAO, 2011). In the European Union, current legislation prescribes that pigs must have permanent access to fresh water (EU, 2009), which is also stated in the Serbian Law on animal welfare (Official Gazette of the RS, No. 41/09). However, water is becoming a critical resource for profitable swine production (Nyachoti and Kiarie, 2011). Natural water resources are progressively diminishing, and environmental pollution is becoming more intense. Generally, it can be stated that testing the quality of water intended for animal consumption is not done routinely by animal producers, who lack knowledge on the negative influence of low-quality water on the swine production. Given that various adverse effects may be produced by providing animals with water which does not meet adequate quality requirements (Valente-Campos et al., 2014), water quality assessment should be part of integrated system of management of agricultural holdings, especially when problems related to productive performance or health-related problems arise.

\section{CONCLUSION}

The scarcity of research into the safety and eligibility of well water intended for swine consumption results in the lack of precise knowledge on the influence of poor-quality water on pig rearing and health. In this research, coliform bacteria (including thermophilic coliforms and Escherichia coli) and organo- 
phosphorus pesticides were repeatedly detected in water samples originating from wells. Consequently, such waters can be considered a potential risk to pigs which consumed them. However, precise assessment/judgement cannot be done due to the fact that whether the criteria given in the Regulation on the drinking water quality (Official Gazette of the FRY, Nos. 42/98 and 44/99, and Official Gazette of the RS No. 28/2019) apply also to water intended for animal consumption. In addition to this, in these legislations the maximum admissible concentrations of organophosphorus pesticides have not been defined. Due to the progressive decline in available water resources and increasing environment pollution, it is necessary that the quality control of water intended for animal consumption be monitored and become part of the integrated management of agricultural holdings, and precise criteria for the assessment of water safety be established.

\section{ACKNOWLEDGMENTS}

This work was supported by the Ministry of Education, Science and Technological Development of the Republic of Serbia and according to innovation voucher number 488 .

\section{Authors' contributions}

SL planned the research and enabled its realisation. GL and NP sampled the water from the wells. DM did the bacteriological investigations. BK did the pesticides analysis. DM and NA wrote the draft manuscript. NA translated it into English and made final corrections.

\section{Competing interests}

The authors declare that they have no competing interests.

\section{REFERENCES}

1. Agriculture and Horticulture Development Board (AHDB) Quarterly, Spring 2019. p. 26. https://pork.ahdb.org.uk/media/276886/pracpigsspring20192364_190215_web.pdf, Approached 30 July 2020.

2. Barcina, I., Gonzalez, J.M., Iriberri, J., Egea, L. 1990. Survival strategy of Escherichia coli and Enterococcus faecalis in illuminated fresh and marine systems. Journal of Applied Bacteriology, 68, 2, 189-198, doi: 10.1111/ j.1365-2672.1990.tb02565.x.. 
3. Bigelow, J.B. and Houpt, T.R. 1988. Feeding and drinking patterns in young pigs. Physiology \& Behavior, 43, 1, 99-109, doi: 10.1016/00319384(88)90104-7.

4. Cabral, J.P.S. 2010. Water Microbiology. Bacterial pathogens and water. Int. J. Environ. Res. Public Health, 7, 10, 3657-3703. doi:10.3390/ ijerph7103657.

5. Chu, M. 2020. The transformed products of disulfoton contribute to cholinesterase inhibition activity on human. Bachelor's Thesis, Environmental and Energy Engineering in collaboration with Environmental Risk Engineering Laboratory, Hokkaido University.

6. Davis, R. 2016. Feedlot design and construction: 5. Water quality. Available at https://www.mla.com.au/globalassets/mla-corporate/research-and-development/program-areas/feeding-finishing-and-nutrition/feedlot-design-manual/05-water-quality-2016_04_01.pdf

7. Dawson, S. 2020. Water: the forgotten nutrient in pigs. https://www.agric. wa.gov.au/water/water-forgotten-nutrient-pigs, Approached 30 July 2020.

8. Donald, D.B., Cessna, A.J., Sverko, E., Gloyier, N.E. 2007. Pesticides in surface drinking-water supplies of the Northern Great Plains. Environmental Health Perspectives, 115 ,8, 1183-1191, doi: 10.1289/ehp.9435.

9. European Commission. Document No SANTE/12682/2019 Analytical quality control and method validation procedures for pesticide residues analysis in food and feed.

10. Edwards, L. 2018. Drinking water quality and its impact on the health and performance of pigs. Final Report prepared for the Co-operative Research Centre for High Integrity Australian Pork. http://porkcrc.com.au/wp-content/uploads/2018/08/2A-118-Drinking-Water-Quality-Final-Report.pdf

11. EPA (Environmental Protection Agency). Method 1699:2007. Pesticides in Water, Soil, Sediment, Biosolids, and Tissue by HRGC/HRMS.

12. Ercumen, A., Pickering, A.J., Kwong, L.H., Arnold, B.F., Parvez, S.M., Alam, M., Sen, D., Islam S., Kullmann C., Chase C., Ahmed R., Unicomb L., S. P. Luby, S.P., Colford, J.M. 2017. Animal feces contribute to domestic fecal contamination: Evidence from E. coli measured in water, hands, food, flies, and soil in Bangladesh. Environmental Science \& Technology 1, 51, 15, 8725-8734, doi: 10.1021/acs.est.7b01710.

13. EU. 2009. Council Directive 2008/120/EC of 18 December 2008 laying down minimum standards for the protection of pigs (Codified version). Official Journal of the European Communities L 47, 5-13.

14. Epp, M. 2019. Water quality: the winning formula for pig production, The Pig Site: https://thepigsite.com/articles/water-quality-the-winning-formu- 
la-for-pig-production.

15. FAO. 2011. The state of the world's land and water resources for food and agriculture (SOLAW) - Managing systems at risk. Food and Agriculture Organization of the United Nations, Rome and Earthscan, London.

16. Gonzalez, J.M., Iriberri, J., Egea, L., Barcina, I. (1992). Characterization of culturability, protistan grazing, and death of enteric bacteria in aquatic ecosystems. Applied and Environmental Microbiology, 58, 3, 998-1004, doi: 10.1128/AEM.58.3.998-1004.1992.

17. Hancock, D.D., Besser, T.E., Kinsel, M.L., Tarr, P.I., Rice, D.H., Paross, M.G. 1994. The prevalence of Escherichia coli O157:H7 in dairy and beef cattle in Washington State. Epidemiology and Infection, 113, 2, 199-207, doi: $10.1017 / \mathrm{s} 0950268800051633$.

18. Health Canada. 2020. Guidance on the use of Enterococci as an indicator in Canadian drinking water supplies. Water and Air Quality Bureau, Healthy Environments and Consumer Safety Branch, Health Canada, Ottawa, Ontario. (Catalogue No. H144-68/2020E-PDF).

19. ISO 9308-1:2014. Water quality - Enumeration of Escherichia coli and coliform bacteria - Part 1: Membrane filtration method for waters with low bacterial background flora.

20. ISO 7899-2:2000.Water quality - Detection and enumeration of intestinal enterococci - Part 2: Membrane filtration method.

21. ISO 16266-2:2018. Water quality - Detection and enumeration of Pseudomonas aeruginosa - Part 2: Most probable number method.

22. ISO 14189:2013. Water quality - Enumeration of Clostridium perfringens - Method using membrane filtration.

23. Jayaraj, R., Megha, P., Sreedev, P. 2016. Organochlorine pesticides, their toxic effects on living organisms and their fate in the environment. Interdisciplinary Toxicology, 9, 3-4, 90-100, doi: 10.1515/intox-2016-0012.

24. Kilb, B., Lange, B., Schaule, G., Flemming, H-C., Wingender, J. 2003. Contamination of drinking water by colifoms from biofilms grown on rubbercoated valves. Int J Hyg Environ Health, 206, 6, 563-573, doi: 10.1078/14384639-00258.

25. Landefeld, M. and Bettinger, J. 2003. Water effects on livestock performance. https://ohioline.osu.edu/factsheet/ANR-13, Approached 30 July 2020.

26. LeChevallier, M.W., Welch, N.J., Smith, D.B. 1996. Full-scale studies of factors related to coliform regrowth in drinking water. Applied and Environmental Microbiology, 62, 7, 2201-2211.

27. Leclerc, H., Mossel, D.A.A., Edberg, S.C., Struijk, C.B. 2001. Advances in the bacteriology of the coliform group: their suitability as markers of 
microbial water safety. Annu. Rev. Microbiol. 55, 201-234, doi: 10.1146/ annurev.micro.55.1.201.

28. LeJeune, J.T., Besser, T.E., Merrill, N.L., Rice, D.H., Hancock, D.D. 2001. Livestock drinking water microbiology and the factors influencing the quality of drinking water offered to cattle. Journal of Dairy Science, 84, 8, 1856-1862, doi: 10.3168/jds.S0022-0302(01)74626-7.

29. Liu, A., Kou, W., Zhang, H., Xu, J., Zhu, L., Kuang, S., Huang, K., Chen, H., Jia, Q. 2020. Quantification of Trace Organophosphorus pesticides in environmental water via enrichment by magnetic-zirconia nanocomposites and online extractive electrospray ionization mass spectrometry. Analytical Chemistry. 92, 5, 4137-45, doi: 10.1021/acs.analchem.0c00304.

30. Manu, S., and Baidoo, S.K. 2020. Nutrition and feeding of swine, In: Animal agriculture: Sustainability, challenges and innovations. Eds. Bazer, F.W., Lamb, C.G., Wu, G. 299-313, doi: 10.1016/C2018-0-01238-4.

31. National Research Council. 1998. Nutrient requirements of swine (10th. ed). National Academy Press, Washington, DC. http://docshare04.dochare.tips/files/27392/273923703.pdf

32. Nyachoti, C.M. and Kiarie, E. 2011. Water in swine production: a review of its significance and conservation strategies. Manitoba swine Semin. 24, 217-232.

33. Official Gazette of the Federal Republic of Yugoslavia, Nos. $42 / 98$ and 44/99, and Official Gazette of the Republic of Serbia, No. 28/2019: Regulations on the quality of drinking water.

34. Official Gazette of the Republic of Serbia, No. 41/09: The law on animal welfare.

35. Paruch, A.M. and Maehlum, T. 2012. Specific features of Escherichia coli that distinguish it from coliform and thermotolerant coliform bacteria and define it as the most accurate indicator of faecal contamination in the environment. Ecological Indicators, 23, 140-142, doi: 10.1016/j.ecolind.2012.03.026.

36. Pfost, D.L. and Fulhage, C.D. 2020. Water quality for livestock drinking. Environmental Quality, MU Guide EQ 381. Approached at https://extension2.missouri.edu/eq381, on 3 August 2020.

37. Radivojević D. 2004. Mehanizacija stočarske proizvodnje, Izdavač: Poljoprivredni fakultet, Beograd.

38. Ramadhaningtyas, D.P. and Aryana, N. 2019. Method development for determination of trace organochlorine pesticides residues in a water matrix by using gas chromatography mass spectrometry (GCMS) method. In: AIP Conference Proceedings. 2175, 020054 (2019), doi: 10.1063/1.5134618. 
39. Smith, G. 2020. Water quality for livestock. https://www.agric.wa.gov.au/livestock-biosecurity/water-quality-livestock?page $=0 \% 2 \mathrm{C} 0 \#$ smartpaging toc_p0_s0_h2, Approached 30 July 2020.

40. Sun, X., Xu, W., Zeng, Y., Hou, Y., Guo, L., Zhao, X., Sun, X. 2014. Metabonomics evaluation of urine from rats administered with phorate under long-term and low-level exposure by ultra-performance liquid chromatography-mass spectrometry. Journal of Applied Toxicology 34, 2, 176-183, doi: $10.1002 /$ jat.2848.

41. Valente-Campos, S., de Souza Nascimento, E., de Aragão Umbuzeiro, G. 2014. Water quality criteria for livestock watering - a comparison among different regulations. Acta Scientiarum. Animal Sciences, 36, 1, 1-10, doi: 10.4025/actascianimsci.v36i1.21853.

42. World Health Organization (WHO), Geneva, 1997. Guidelines for drinking-water quality, Second Ed., Volume 3 Surveillance and control of community supplies. https://www.who.int/water_sanitation_health/dwq/ gdwqvol32ed.pdf?ua=1

Received: 14.08.2020.

Accepted: 01.11.2020. 